Olga Tytko

Uniwersytet Śląski w Katowicach

(D) https://orcid.org/0000-0002-3440-6522

\title{
Więźniowie na rynku pracy - analiza doświadczeń polskich i zagranicznych
}

\begin{abstract}
The article discusses the issues related to the employment of prisoners in Poland and in other countries. The author refers to some legal provisions regulating the question of who can undertake an employment while serving time in prison, what requirements must be met by convincts who work while imprisoned. Then, the article discusses particular professions performed by prisoners. An important element of the article is also apresentation of socio-psychological aspects of rendering work while incarcerated. Since one of the reasons for writing this article was the announcement in 2016 of the "Work for prisoners" programme, a significant part of the article is devoted to discussion of this project. An attempt is made to answer the question: Has the governmental programme in question proved successful? Instrumental in answering this question is a comparison of a number of prisoners before the start of the said programme, and while being a part of its operation. The article also includes some examples of influencing prisoners already successfully implemented in other countries.
\end{abstract}

Key words: prison, prisoners work, work of prisoners in the world, government program "Work for a prisoner"

\section{Wstęp}

Niniejszy artykuł poświęcony jest sytuacji więźniów w Polsce i w innych wybranych krajach. Porusza aspekty związane z zatrudnieniem tej grupy podczas odbywania wyroku, nie przedstawia jednak konkretnych przykładów, ale rozwiązania prawne.

Tematyka ta jest ważna z kilku powodów: po pierwsze więźniowie są jedną z grup najsilniej narażonych na wykluczenie społeczne (Kubat, 2010, 
s. 139-146), dlatego wszelkie próby przywracania ich do życia społecznego są bardzo potrzebne. Po drugie obecnie, w czasach, gdy brakuje rąk do pracy, coraz częstszym pomysłem na znalezienie pracowników jest właśnie wykorzystanie potencjału więźniów. Warto przeanalizować obecną sytuację w tym względzie, a także przykłady dobrych, funkcjonujących już praktyk w zatrudnieniu więźniów. $\mathrm{Z}$ całą pewnością można w tym aspekcie posiłkować się doświadczeniami innych krajów, w których być może resocjalizacja jest bardziej skuteczna niż w Polsce. Ważnym powodem, dla którego warto analizować sytuację więźniów na rynku pracy, jest też wejście w życie w Polsce rządowego programu „Praca dla więźniów”. Podstawę funkcjonowania programu stanowią przepisy następujących aktów prawnych: Ustawy z dnia 28 sierpnia 1997 roku o zatrudnianiu osób pozbawionych wolności (Dz.U. z 2014 r. poz. 1116, z późn. zm.), Ustawy z dnia 6 czerwca 1997 roku Kodeks Karny Wykonawczy (Dz.U. 1997, Nr 90 poz. 557, z późn. zm.), a także rozporządzenie Ministra Sprawiedliwości z dnia 30 maja 2017 roku w sprawie Funduszu Aktywizacji Zawodowej Skazanych oraz Rozwoju Przywięziennych Zakładów Pracy (Dz.U. z 2017 r. poz. 1069), a wcześniej rozporządzenie Ministra Sprawiedliwości z dnia 23 stycznia 2012 roku (Dz.U. z 2014 r. poz. 53; https://www. sw.gov.pl/strona/ministerialny-program-pracy-wiezniow [dostęp: 30.11.2018]). Powstawanie tego typu inicjatyw powinno skłonić media czy środowiska naukowe do poświęcenia większej uwagi sytuacji więźniów na rynku pracy w Polsce. Bez wątpienia wprowadzenie programu, którego celem jest zwiększenie liczby pracujących więźniów, stanowi powód, dla którego należałoby prowadzić analizy liczby pracujących w Polsce więźniów — będzie to odpowiedź na pytanie o skuteczność prowadzonych działań. Analizy dotyczące liczebności pracujących więźniów są też istotne, aby przynajmniej spróbować odpowiedzieć na pytanie, czy potencjał, którym bez wątpienia są więźniowie, jest wykorzystywany. Z kolei kwestia opinii społecznej na temat pracy więźniów może być ważnym punktem wyjścia do rozważań na temat tego, jak zwiększyć liczbę pracujących więźniów.

Bardzo ważnym aspektem jest również pewnego rodzaju rehabilitacja społeczna, która może się dokonać dzięki podjęciu przez więźniów lub byłych więźniów pracy (Pstrąg, 2014, s. 150-153). Jest to kolejny aspekt, na który chciałabym zwrócić uwagę w swoim artykule.

Niniejsze rozważania są próbą odpowiedzi na następujące pytania:

- Jakie zawody wykonują więźniowie i byli więźniowie?

- Jakie kryteria muszą spełniać więźniowie, aby móc pracować podczas odbywania wyroku?

- Czy dla więźniów praca jest przymusem czy przywilejem?

- Czy praca jest elementem resocjalizacji więźniów?

Częścią odpowiedzi na pytania będzie również przedstawienie obrazu więźniów i byłych więźniów w oczach pracodawców.

Ze względu na pytania badawcze postawione na początku tej części artykułu jego treść będzie analizą źródeł zastanych, zarówno aktów prawnych, jak i artykułów naukowych i popularnych poświęconych tematyce pracy więźniów, czy też opiniom społeczeństwa o więźniach i dopuszczaniu ich do pracy. 


\section{Program „Praca dla więźniów”: podstawy prawne, cele, założenia, finansowanie}

Program „Praca dla więźniów” został powołany przez wiceministra sprawiedliwości Patryka Jakiego w 2016 roku (https:/www.sw.gov.pl/strona/ministerialnyprogram-pracy-wiezniow [dostęp: 30.11.2018]). Celem programu jest readaptacja społeczna więźniów, czyli doprowadzenie do takiej sytuacji, w której będą oni funkcjonować zgodnie z normami społecznymi. Zadania związane z readaptacją są realizowane w głównej mierze przez Służbę Więzienną, a narzędziem wykonywania zadania jest praca zawodowa. Program oparty jest na następujących aktach prawnych:

- Ustawie z dnia 28.08.1997 r. o zatrudnieniu osób pozbawionych wolności (Dz.U. z 2014 r. poz. 1116 z późn. zm.);

— Ustawie z dnia 6.06.1997 r. Kodeks Karny Wykonawczy (Dz.U. 1997 Nr 90 poz. 557, z późn. zm.);

- Rozporządzeniu Ministra Sprawiedliwości z dnia 30.05.2017 r. w sprawie Funduszu Aktywizacji Zawodowej Skazanych oraz Rozwoju Przywięziennych Zakładów Pracy (Dz.U. z 2017 r. poz. 1069), a wcześniej rozporządzeniu Ministra Sprawiedliwości z dnia 23 stycznia 2012 r. (Dz.U. z 2014 r. poz. 53).

Ustawodawca przyjął trzy główne cele, które ma spełniać wprowadzony program (https://www.sw.gov.pl/strona/ministerialny-program-pracy-wiezniow [dostęp: 2.10.2018]):

- budowę w zakładach karnych hal produkcyjnych, hal ma powstać 40; przewidywany termin realizacji tego zadania to lata 2016-2023;

- rozszerzenie zakresu możliwości nieodpłatnej pracy więźniów na rzecz samorządów; od 1 kwietnia 2017 roku zostało wprowadzone ustawowe zwiększenie kręgu podmiotów, które będą miały prawo nieodpłatnie zatrudniać osoby osadzone, wymiar zatrudnienia to maksymalnie 90 godzin w miesiącu;

- ulgi dla przedsiębiorców, którzy zdecydują się zatrudnić więźniów; ryczałt jest wypłacany obligatoryjnie i obecnie prawo do niego ma już ponad 300 firm, ale poza ryczałtem te firmy, które zdecydują się na zatrudnienie osób odbywających wyroki więzienia, mają prawo do dotacji i pożyczek na cele związane z działaniami mającymi wpływać na resocjalizację poprzez pracę (dane Centralnego Zarządu Służby Więziennej).

Jak wskazują dane, które udostępnił na swojej stronie Centralny Zarząd Służby Więziennej, program spełnia swoje zadanie w zakresie zwiększenia zatrudnienia w omawianej grupie (https://www.sw.gov.pl/strona/ministerialny-program-pracywiezniow [dostęp: 3.10.2018]). Świadczy o tym zwiększenie o niemal 12\% liczby pracujących osadzonych w ciągu 2 lat działania projektu. Kolejnym wymiernym efektem omawianej inicjatywy jest zwiększenie wskaźnika powszechności zatrudnienia osadzonych do 53,42\%. W końcu czerwca 2018 roku pracowało 35,6 tys. więźniów. Na stronie Centralnego Zarządu Służby Więziennej (https:/www.sw.gov. $\mathrm{pl} /$ strona/ministerialny-program-pracy-wiezniow [dostęp: 3.10.2018]) można prze- 
czytać, że program jest finansowany przede wszystkim przez samych więźniów. Im więcej więźniów pracuje, tym więcej pieniędzy z ich pracy jest przeznaczanych na Fundusz Aktywizacji Zawodowej Skazanych oraz Rozwoju Przywięziennych Zakładów Pracy, ale również coraz więcej pieniędzy może być przeznaczonych na wypłacenie tym pracodawcom, którzy zdecydują się na zatrudnienie osób skazanych, ryczałtu związanego ze zwiększonymi kosztami zatrudnienia osób pozbawionych wolności. Obecnie ryczałt ten wynosi 35\%. Przed wprowadzeniem programu było to $20 \%$. W pierwszych dwóch latach obowiązywania programu wybudowano 13 hal, w których pracuje kilkaset osób w trakcie odbywania kary (na podstawie danych Centralnego Zarządu Służby Więziennej: https:/www.sw.gov.pl/ strona/ministerialny-program-pracy-wiezniow [dostęp: 4.10.2018]).

Analizując program „Praca dla więźniów”, warto zauważyć, że przynosi on korzyści zarówno pracodawcom, którzy zdecydują się na skorzystanie z niego, jak i samym osadzonym. Więźniowie mogą w uczciwy sposób wypracować sobie wynagrodzenie w kwocie nie niższej niż minimalne wynagrodzenie za pracę, jeśli tylko konkretna osoba jest zatrudniona w pełnym wymiarze godzin i rzeczywiście taką liczbę godzin wypracuje. Poza tym mają możliwość bezpłatnie przyuczyć się do zawodu, który będą mogli wykonywać również po opuszczeniu zakładu karnego. Kolejną korzyścią dla więźnia jest wspomniana już możliwość partycypowania w utrzymaniu swojej rodziny czy spłacenia ewentualnego zadłużenia. Dużą korzyścią dla więźniów są działania związane z resocjalizacją i partycypacją w życiu społecznym, a więc poczucie bycia potrzebnym, ciągła aktywność zbliżona do życia na wolności. Pomaga to w utrzymaniu dobrostanu psychicznego i fizycznego. Dla pracodawców program niesie korzyści polegające na możliwości powierzenia pracy osobie, której nie muszą u siebie zatrudniać, co znacząco obniża koszt. Nie trzeba bowiem opłacać składek, należy natomiast przestrzegać przepisów BHP oraz tych, które dotyczą czasu pracy. Kolejnym ułatwieniem dla pracodawcy jest możliwość wnioskowania o zmianę miejsca lub rodzaju wykonywania przez osadzonego pracy bez konieczności zachowywania terminów wynikających z Kodeksu Pracy. Z pracy więźnia można również po prostu zrezygnować bez konieczności stosowania formalnego wypowiedzenia i innych zapisów kodeksowych, które obowiązują wobec zatrudnionych pracowników. Jest to też sposób na pozyskanie dodatkowych środków finansowych, które muszą być jednak spożytkowane na cele związane $\mathrm{z}$ resocjalizacją albo wprost ze stworzeniem nowych miejsc pracy dla osadzonych oraz utrzymanie już istniejących (https:// www.sw.gov.pl/strona/ministerialny-program-pracy-wiezniow [dostęp: 4.10.2018]).

Chcąc doszukać się w omawianym projekcie minusów, można wskazać na fakt, że spora kwota została przekazana na wybudowanie hal, w których będą pracować więźniowie na terenie więzień, co może osłabić działania resocjalizacyjne, ponieważ daje zdecydowanie mniejsze możliwości kontaktu ze światem niż praca poza murami więzienia. Takie rozwiązanie pozwala jednak na zaoferowanie pracy tym osadzonym, którzy nie otrzymują pozwolenia na pracę na wolności, a ponadto zwiększa liczbę miejsc pracy dla więźniów nie uszczuplając jednocześnie ogólnej liczby miejsc pracy (dane Centralnego Zarządu Służby Więziennej). 


\section{Powody powstania artykułu}

Problem osób przebywających w zakładach penitencjarnych wart jest uwagi badawczej między innymi ze względu na zmiany prawne (wprowadzenie programu „Praca dla więźniów”) oraz zmiany na rynku pracy. Więźniowie pracowali również przed wprowadzeniem programu, jednak, jak zostanie wskazane w dalszych częściach artykułu, obecnie praca więźniów staje się coraz popularniejsza i częściej wykorzystywana. Jest to tendencja obowiązująca w Polsce. To, że polski rząd zdecydował się na wprowadzenie programu aktywizacji zawodowej więźniów, jest dowodem po pierwsze na istotność społeczną problemu, po drugie na to, że podejmowane starania, aby wzrastała liczba osób, które będą podlegać resocjalizacji przez pracę. O możliwościach zatrudniania osób przebywających w zakładach karnych warto również wiedzieć (i informować), ponieważ więźniowie mogą uzupełniać braki kadrowe zwłaszcza w przypadku pracowników produkcyjnych i tych na najniższych stanowiskach, których deficyt jest największy (Barometr Zawodów 2018: „Deficyt pracowników na polskim rynku pracy pogłębia się”)'. Warto również popularyzować pracę więźniów, ponieważ wpływa ona w sposób pozytywny na ich resocjalizację i na zmniejszenie stopnia ich izolacji od społeczeństwa w porównaniu do tych osadzonych, którzy nie mieli możliwości skorzystania z pozwolenia na pracę podczas odbywania wyroków (Łuczak, 2016).

\section{Możliwości zatrudnienia oferowane polskim więźniom}

W Polsce więźniowie przeważnie wykonują prace fizyczne: pracują w fabryce mebli, bardzo często zajmują się pracami ogólnobudowlanymi, remontowymi, często jako pracownicy produkcji na przykład okien, drzwi czy przy produkcji, obróbce i wytwarzaniu żywności (Ł u czak, 2016). Znacząca część polskich więźniów jest zatrudniona przy pracach porządkowych i pomocniczych o charakterze administracyjno-gospodarczym. Jeśli pracują na terenie samego zakładu karnego, to przeważnie w kuchni, w bibliotece, w pralni (Łuczak, 2016). Co ważne, pomimo że osoby odbywające wyroki są kierowane najczęściej do prac zgodnych ze swoimi kwalifikacjami, mają również możliwość nabycia nowych umiejętności podczas odbywania kary. Możliwe jest podejmowanie kursów dających określony zawód, a nawet studiowanie na wyższej uczelni (Mrózek, 2014, s. 54).

\footnotetext{
${ }^{1}$ Barometr Zawodów został przygotowany przez wojewódzkie urzędy pracy na zlecenie Ministerstwa Rodziny, Pracy i Polityki Społecznej. Ma na celu wskazanie najważniejszych i najbardziej aktualnych tendencji na rynku pracy. Według prognoz zawartych w Barometrze na 2018 rok w roku tym nadal występują problemy ze znalezieniem pracowników. Prognozowany jest też wzrost liczby zawodów deficytowych i zmniejszenie liczby zawodów nadwyżkowych — tendencja ta ma się utrzymywać zwłaszcza w dużych miastach.
} 


\section{Praca więźniów w liczbach}

Jak wynika z dostępnych danych, liczba pracujących więźniów wzrasta, i to w sposób dynamiczny. Dane z końca maja 2016 roku wskazywały, że w omawianym okresie pracowało 30\% osadzonych (natomiast według informacji z października 2017 roku odsetek ten wynosi 45\% wszystkich przebywających w zakładach penitencjarnych; Ministerstwo Sprawiedliwości: Sukces programu „,Praca dla więźniów”, na podstawie: https://www.ms.gov.pl/pl/informacje/news,10016,sukcesprogramu-praca-dla-wiezniow.html [dostęp: 4.10.2018] oraz Kubicki, 2016). Porównując te dane ze stanem z połowy lat 90. XX wieku, można odnotować w Polsce znaczący wzrost liczby pracujących więźniów (Kubicki, 2016). W 2014 roku pracowało w Polsce ok. 34,7\% więźniów, a w 2013 roku mniej więcej 31,5\%. Większość z osadzonych w latach 2013-2014 pracowała na terenie samych zakładów karnych (Kubicki, 2016). W roku 1995 w Polsce pracowało zaledwie 25\% skazanych, a wskaźnik bezrobocia w tej grupie sięgał wówczas niemal 50\%. Liczba pracujących więźniów w Polsce jest drastycznie mniejsza niż w innych krajach naszego kontynentu, bo dla przykładu na Węgrzech, w Niemczech czy na Słowacji odsetek pracujących więźniów sięgał aż 85\% (http:// docplayer.pl/5393378-Praca-skazanych-w-polskim-systemie-penitencjarnymod-1925-r.html [dostęp: 20.11.2017]).

Bardzo niekorzystne są też wskaźniki dotyczące umów, na jakich pracują więźniowie. W omawianym roku 2015 tylko 4\% więźniów pracowało w oparciu o umowę zlecenie lub umowę o dzieło. Jeszcze mniejsza jest liczba osób osadzonych, które otrzymały umowę o pracę. Było ich w tamtym okresie jedynie 3\%. Więźniowie najczęściej nie wyrabiali też całego etatu, a ich wynagrodzenie nie sięgało najniższej krajowej (http://docplayer.pl/5393378-Praca-skazanych-w-pol skim-systemie-penitencjarnym-od-1925-r.html [dostęp: 20.11.2017]).

Sytuację tej grupy na rynku pracy poprawił wprowadzony w 2016 roku program „Praca dla więźniów”. Jak wskazują inne statystyki, o których mowa w tym samym artykule, w grudniu 2016 roku liczba zatrudnionych więźniów wynosiła 12,5 tys., a ok. 1/3 znalazła zatrudnienie w firmach zewnętrznych. Liczba zatrudnionych w firmach zewnętrznych wzrosła więc o 60\% w skali roku (http:// www.tvp.info/28094640/wiezniowie-lataja-dziury-na-rynku-pracy-odplatniepracuje-juz-125-tys-skazanych [dostęp: 6.09.2017]).

\section{Socjologiczno-psychologiczne skutki pracy więźniów}

Dla samych osób odbywających karę więzienia praca jest nagrodą (http://wybor cza.pl/1,155287,17349066,Gdy_zatrudnienie_jest_nagroda_14_5_tys__wiezniow. html [dostęp: 2.10.2018]). Ma to kilka uzasadnień. Nie każdy więzień może praco- 
wać. Część z nich ze względu na charakter czynu, którego się dopuścili, nigdy nie otrzymuje zgody na pracę poza więzieniem. Poza tym pracujący więźniowie czują się potrzebni - zarówno społeczeństwu, jak i swoim rodzinom. Dzięki temu, że sami pracują, mogą chociażby płacić alimenty czy wspomagać finansowo swoje rodziny, które pozostały na wolności. Dlatego podczas wyboru osadzonych, którzy będą pracować, pierwszeństwo mają ci, którzy na wolności mają dzieci. Jeszcze jednym warunkiem podjęcia pracy podczas odbywania kary więzienia jest co najmniej 3-letni wymiar kary (Stanowska, 2014). Przepisy o pracy więźniów są obecnie tak skonstruowane, że osoby, które się zdecydują na pracę, są za nią dodatkowo nagradzane przez system penitencjarny. Do dodatkowych nagród zalicza się dłuższy czas widzeń lub ich większa ilość, możliwość dłuższego przebywania na spacerniaku, pierwszeństwo przy wyborze osób, które będą mogły brać udział w zajęciach rozrywkowych i kulturalnych organizowanych przez zakład, w którym odbywają karę, czy też możliwości kupienia w więziennej kantynie większej ilości towarów dozwolonych na terenie więzienia (Kodeks karny wykonawczy, rozdz. 5, art. 124). Ważnym elementem pracy więźniów jest jej resocjalizujący charakter. Więźniowie, którzy pracują, nie odzwyczajają się od obowiązku pracy, niejednokrotnie nabywają nowych umiejętności, poza tym - co bardzo istotne przebywają dużą część czasu w środowisku otwartym, a więc mają częsty kontakt ze światem zewnętrznym, co pozwala na łatwiejszy powrót do normalnego życia po odbyciu kary. Nie nabywają nawyków więziennych w tak dużym stopniu jak osoby, którym pracy podczas odbywania wyroku odmówiono.

Stały kontakt ze światem ludzi wolnych jest ważny, ponieważ więzienie jest instytucją totalną — jak zauważa Erving Goffman w książce Instytucje totalne. $O$ pacjentach szpitali psychiatrycznych i mieszkańcach innych instytucji totalnych - co oznacza, że osoby przebywające w nim są traktowane jako podlegające - używając określeń Goffmana - „procesom deprywacji osobowości”, a jednocześnie fizycznie są odizolowane od codziennych czynności życiowych poza taką instytucją. Dodatkowo w instytucji totalnej mają miejsce przejawy manipulacji personelu wobec „pensjonariuszy”, więźniów. Autor wskazuje też na „wytwarzanie się wśród osób przebywających w instytucjach totalnych nieformalnego zestawu zachowań, nieformalnej kultury" (Goffman, 2011 [1957], s. 15-17). W więzieniach są to zachowania pogłębiające wzorce patologiczne, przestępcze. Zakłady penitencjarne $\mathrm{z}$ całą pewnością wpisują się $\mathrm{w}$ tę definicję. Przebywający w nich jedzą, śpią, mieszkają wciąż w tym samym miejscu. Praca pozwala im więc, choć w pewnym zakresie, nie odzwyczaić się od życia na wolności.

Jak wskazują opracowane już badania (Łuczak, 2016, s. 111), polscy więźniowie to przeważnie osoby z niskim wykształceniem, podstawowym lub zawodowym. W więzieniach mają możliwość uczenia się i kończenia różnych szkół, ale nie wszyscy więźniowie mogą z tego korzystać. Podobnie jak w przypadku pracy więźniów tak i w przypadku edukacji więcej jest chętnych niż miejsc. Poza tym w części przypadków na przeszkodzie stoją braki we wcześniejszej edukacji (Łuczak, 2016, s. 111). Informacje o niskim wykształceniu osadzonych potwierdza

126 jednoznacznie kierownik Zakładu Resocjalizacji Uniwersytetu Adama Mickiewi- 
cza profesor Wiesław Ambrozik w wywiadzie z końca września 2017 roku (http:// www.rp.pl/Przestepczosc/170928957-Prof-Wieslaw-Ambrozik-Miec-wiezniow-jakw-Niemczech.html\#ap-1 [dostęp: 30.09.2017). Mówi on, że obecnie na ok. 80 tysięcy osadzonych ponad $70 \%$ to osoby z wykształceniem nie wyższym niż zawodowe, a często podstawowym. Oznacza to, że na przestrzeni ponad 10 lat sytuacja w zakresie wykształcenia osadzonych się nie zmieniła. Jednocześnie jednak profesor zaznacza, że zdarzają się również więźniowie nawet po studiach wyższych. Najczęściej wciąż są to osoby z niskim wykształceniem, ze zmarginalizowanych środowisk, w których o wykształcenie nikt nie zadbał, a im samym też nie wydawało się ono istotne (http://www.rp.pl/Przestepczosc/170928957-Prof-WieslawAmbrozik-Miec-wiezniow-jak-w-Niemczech.html\#ap-1 [dostęp: 30.09.2017]).

\section{Prawne i formalne podstawy pracy więźniów w Polsce}

Zgodnie z wyrokiem Trybunału Konstytucyjnego od 2010 roku więźniowie otrzymują pensję w wysokości nie mniejszej niż minimalna płaca krajowa. Warunkiem otrzymania takiego wynagrodzenia jest przepracowanie liczby godzin równej pełnemu etatowi. Wcześniej mogli liczyć tylko na połowę tej sumy, nawet pracując „na pełen etat” (Dz.U. $2010 \mathrm{nr} 34$ poz. 191, Wyrok z dn. 23.02.2010 r. Sygn. akt P20/09). Pracodawcy zatrudniający więźniów mogą ubiegać się o zwrot 35\% poniesionych kosztów. Firmy mogą również ubiegać się o pieniądze na przykład na wybudowanie i wyposażenie na terenie więzienia swojej filii, w której pracować będą osoby odbywające karę pozbawienia wolności, przebywające w danym zakładzie karnym. Przygotowywanie miejsc pracy na terenie zakładów karnych jest istotne nie tylko ze względu na umożliwienie pracy tym więźniom, którzy nie otrzymali zgody na pracę poza więzieniem; pozwala też na zwiększenie liczby miejsc pracy dla więźniów:

W polskim Kodeksie karnym wykonawczym (rozdz. 5, art. 123-123a) jest też bardzo jasno zaznaczone, które prace mogą być przez więźniów wykonywane nieodpłatnie. Są to prace porządkowe lub pomocnicze, a beneficjentami tego rodzaju pracy są albo same zakłady, w których więźniowie odsiadują kary, albo społeczności lokalne. W tej sytuacji jedna osoba nie może miesięcznie wyrobić więcej niż 90 godzin. Osoba, która miałaby w taki sposób pracować, musi wyrazić na to zgodę (Kodeks karny wykonawczy, rozdz. 5, art. 123-123a). Wynika to z zapisów artykułu 8, ustępu nr 3 Międzynarodowego Paktu Praw Obywatelskich i Politycznych, w którym mowa między innymi o tym, że nie wolno nikogo zmuszać do pracy przymusowej lub obowiązkowej (wyjątkiem są te kraje, w których ciężka praca jest elementem kary pozbawienia wolności). Warto w tym miejscu zaznaczyć, że omawiany dokument precyzuje również pojęcie pracy przymusowej i ciężkich prac (Międzynarodowy Pakt Praw Obywatelskich i Politycznych, art. 8, ustęp 3). Poza zgodą samego osadzonego na pracę podczas odbywania kary więzie- 
nia oraz poza spełnianiem odpowiednich warunków finansowych, o czym mowa była wcześniej, praca więźniów musi spełniać jeszcze kilka istotnych warunków. Po pierwsze, ma być efektywna i przynosić korzyść zarówno pracodawcy, jak i społeczeństwu, ale również osobie, która ją wykonuje. Co więcej, praca osadzonych musi odbywać się $\mathrm{w}$ warunkach co najmniej zbliżonych do normalnych, w tym muszą być przestrzegane normy pracy dotyczące bezpieczeństwa i przepisów BHP. Określone są też normy czasu pracy. Ramy czasowe określają nie tylko wspomnianą liczbę godzin w przypadku pracy nieodpłatnej, mają również pozwalać na pogodzenie pracy osadzonych z ich innymi czynnościami, jak nauka, odpoczynek, rekreacja (Kubicki, 2016).

\section{Przykłady rozwiązań dotyczących pracy więźniów w innych krajach}

Nie tylko polski system prawny przewiduje nagrody dla osadzonych, którzy zdecydują się na pracę podczas pobytu w zakładzie karnym. Polska nie jest też jedynym krajem, w którym więźniowie muszą wyrazić zgodę na pracę. Na Łotwie na przykład, podobnie jak w Polsce, osoby odbywające karę pozbawienia wolności mogą być zatrudnione zarówno za wynagrodzeniem, jak i bez wynagrodzenia. Wynagrodzenie może być pracującym więźniom wypłacane za czynności związane $\mathrm{z}$ utrzymaniem zakładu karnego, za pracę wykonywaną w przywięziennych zakładach pracy, a także za pracę wykonywaną poza zakładem karnym, jeśli została na to wyrażona zgoda kierownictwa danego więzienia. Łotewscy więźniowie pracujący z zachowaniem wynagrodzenia nie mogą otrzymywać mniej niż 50\% najniższej pensji krajowej. Na Łotwie na rzecz zakładu karnego więźniowie mogą też pracować nie otrzymując za to wynagrodzenia (Kubicki, 2016).

W Holandii, podobnie jak w Polsce, więźniowie mogą odbyć szkolenia, dzięki którym nabędą nowych kwalifikacji. Po ich ukończeniu niejednokrotnie wykonują prace społecznie użyteczne, na przykład na rzecz społeczności lokalnych. Do takich prac mogą należeć remonty osiedli domów jednorodzinnych, osiedli socjalnych, miejsc zamieszkałych w dużym stopniu przez osoby starsze. Taki rodzaj prac, jak ocenia profesor Wiesław Ambrozik (http://www.rp.pl/Przestepczosc/170928957Prof-Wieslaw-Ambrozik-Miec-wiezniow-jak-w-Niemczech.html\#ap-1 [dostęp: 30.09.2017]), nosi znamiona resocjalizacji i spełnia jej funkcję, a jednocześnie pozwala na integrację społeczną więźniów ze społecznościami lokalnymi, w których wykonują oni swoją pracę. Również w Niemczech więźniowie pracują. Jak mówi cytowany profesor, ,wykonują oni bardzo wiele prac, od prostych do specjalistycznych. Wachlarz prac więźniów rozciągał się od łatwego składania plastikowych zabawek, po wymagające umiejętności wykonywanie elementów turbin samolotowych dla wojska. Więźniowie dysponowali parkiem maszynowym, o jakim największe fabryki w Polsce mogły wówczas tylko pomarzyć" (http:// 
www.rp.pl/Przestepczosc/170928957-Prof-Wieslaw-Ambrozik-Miec-wiezniow-jakw-Niemczech.html\#ap-1 [dostęp: 30.09.2017]).

Korzystne dla osób odbywających karę pozbawienia wolności przepisy związane z pracą obowiązują w Grecji. Kraj ten, pomijając już nawet fakt posiadania w Konstytucji zapisów o dobrowolności pracy więźniów, przyjął inny ciekawy zapis. Chodzi mianowicie o możliwość skrócenia kary tym więźniom, którzy zdecydują się na pracę podczas odbywania kary lub pobytu w areszcie. Przepisy greckie stanowią, że w zależności od rodzaju pracy za każdy przepracowany dzień można skrócić sobie wyrok o $1-2$ dni. Skorzystać z tego przywileju mogą również niektórzy osadzeni w aresztach, w zależności od rodzaju przestępstwa, którego się dopuścili. Część pieniędzy wypracowanych przez osadzonych przeznaczona jest na utrzymanie więzień (Kubicki, 2016).

W Wielkiej Brytanii przepisy dotyczące pracy więźniów są dla odmiany zdecydowanie bardziej rygorystyczne. Więźniowie mają obowiązek wykonywać zleconą im pracę. Ma ona nosić znamiona użyteczności. Uchylanie się od zleconej pracy jest traktowane jako wykroczenie dyscyplinarne, a nagradzanie za pracę w brytyjskim systemie prawnym traktowane jest jako możliwe, a nie obligatoryjne. Skazanym w Wielkiej Brytanii nie przysługuje minimalne wynagrodzenie. $\mathrm{Na}$ Wyspach Brytyjskich powszechne jest, że więźniowie pracują w firmach poza więzieniem (Kubicki, 2016).

Kolejnym krajem o bardzo ciekawym podejściu do pracy więźniów jest Hiszpania. Przede wszystkim na terenie tego kraju funkcjonuje specjalny organ, stworzony do szkolenia i kierowania do pracy osób przebywających w więzieniach lub aresztach śledczych. Podejście do pracy więźniów wydaje się więc bardzo profesjonalne, ujednolicone i przemyślane. Służba ta finansowana jest ze środków Europejskiego Funduszu Społecznego. Co więcej, oddzielne regulacje dotyczące pracy więźniów posiada Katalonia - obszar będący oficjalnie częścią Hiszpanii, starający się jednak o niepodległość. Na terenie tego regionu przepisy przewidują, że zakłady karne mogą we współpracy z przedsiębiorstwami zewnętrznymi tworzyć przywięzienne fabryki (Kubicki, 2016).

Portugalski system penitencjarny zakłada, że więźniowie mogą pracować zarówno na terenie więzienia, jak i w firmach poza nim. W Portugalii wynagrodzenia dla więźniów nie są wysokie - wynoszą 60-100 euro miesięcznie, a co więcej, tylko część wynagrodzenia pozostaje do ich dyspozycji. Wynagrodzenie portugalskich więźniów dzielone jest na trzy lub cztery części. Jedna część jest oddawana więźniom w momencie opuszczania zakładu karnego, do tego czasu znajduje się w depozycie, druga część jest przeznaczana na grzywny lub inne kary zasądzone danej osobie. Kolejna część z tego, co zarobią więźniowie, może być przez nich wydatkowana na bieżące potrzeby. Ostatnia część wynagrodzenia wydzielana jest wobec tej grupy więźniów, którzy obciążeni są obowiązkiem alimentacyjnym (Kubicki, 2016).

Również we Włoszech dopuszcza się pracę więźniów. Włoscy więźniowie mogą pracować zarówno na terenie zakładu karnego, w którym przebywają, jak i na terenie zakładów znajdujących się poza więzieniem. Jedynie więźniowie 
odbywający wyrok za zbrodnię nie mogą pracować na zewnątrz. Pomimo tego, że pod względem finansowym przepisy włoskie dotyczące pracy więźniów wydają się korzystne (nie mogą oni otrzymać mniej niż $2 / 3$ wynagrodzenia za taką samą pracę, jakie otrzymuje pracownik zatrudniony na umowę o pracę), we Włoszech pracuje niewielka liczba więźniów, bo jedyne $20 \%$. Włochy nie mają po prostu dobrze przygotowanego systemu wsparcia pracy więźniów. Oczywiście w zakładach włoskich część wynagrodzenia więźniów jest przeznaczana na ich utrzymanie czy na kary, które mają do spłacenia (Kubicki, 2016).

W opozycji do przepisów włoskich stoją przepisy francuskie. We Francji zakłady karne mają dołożyć wszelkich starań, aby więźniowie, którzy chcą pracować, mogli to robić. W tym kraju liczba więźniów wykonujących pracę w zakładach, w których odbywają wyroki, jest wysoka, wynosi ona około $50 \%$ ogólnej liczby osadzonych. Wynagrodzenie tej grupy więźniów, która zatrudnienie znalazła w samym zakładzie penitencjarnym, wynosi $33 \%$ minimalnej krajowej. Dla osób, które pracują poza zakładem karnym, jest nieco wyższe i wynosi 45\% minimalnej krajowej (Kubicki, 2016).

Bardzo ciekawy system łagodzenia kary wprowadzono w Brazylii. W 2012 roku wprowadzono tam program pozwalający na skrócenie wyroku dzięki nauce i czytaniu książek. Jest on nazywany „Odkupienie poprzez naukę” lub „Odkupienie poprzez lekturę". W myśl tego programu za każdą przeczytaną książkę, która należy do kanonu brazylijskiej klasyki lub jest związana z nauką lub filozofią, kara ulega skróceniu o 4 dni. Limit książek na rok to 12, a więc o 48 dni w ciągu roku można w ten sposób zmniejszyć sobie wymiar kary. Trudność tego z pozoru banalnego zadania może być dla brazylijskich więźniów jednak spora, ponieważ przeczytanie wybranych książek trzeba udowodnić, pisząc na ich temat wypracowania, a poziom wykształcenia wśród Brazylijczyków jest bardzo niski. 8\% więźniów stanowią analfabeci, a 70\% z nich nie ma nawet podstawowego wykształcenia (https://pl.globalvoices.org/2012/08/brazylia-jedna-przeczytana-ksiazka-too-cztery-dni-krotszy-pobyt-w-wiezieniu/ [dostęp: 30.09.2017]). Przedstawione rozwiązania, pomimo że nie odwołują się do rozwiązań polskich, wydają się jednak ciekawe i warte przeanalizowania, głównie ze względu na ich charakter edukacyjny i resocjalizacyjny dostosowany do realiów, które panują w poszczególnych krajach.

\section{Ekonomiczny wymiar pracy osób odbywających kary więzienia w Polsce}

Jak już wspomniano, pobyt więźniów w zakładzie karnym jest kosztowny. Właśnie dość wysokie koszty związane z utrzymaniem każdego z osadzonych w zakładach karnych są pierwszą przesłanką do tego, by spopularyzować zjawisko pracy więźniów. Kolejnym pozytywnym wymiarem aktywizacji zawodowej więźniów jest możliwość spłacania za siebie zobowiązań zaciągniętych na wolności czy 
wspomagania finansowo swoich rodzin. Ta możliwość jest również odciążeniem dla państwa. Wpływa bowiem między innymi na obniżenie kosztów związanych $\mathrm{z}$ funduszem alimentacyjnym. Jeśli osoby przebywające $\mathrm{w}$ więzieniu płacą alimenty, zwolnione z tego obowiązku jest państwo, a także niższe koszty są ponoszone przez pomoc społeczną, ponieważ jeśli skazani wysyłają do swoich rodzin pieniądze zarobione $\mathrm{w}$ więzieniu, to rodziny te nie muszą zwracać się o pomoc do służb społecznych. Praca więźniów może mieć również i inne pozytywne skutki finansowe, i to w znacznie szerszym wymiarze. Więźniowie pracujący na terenie zakładu karnego, w którym przebywają, przyczynić się mogą do mniejszego zapotrzebowania na personel w tym zakładzie. W każdym przypadku praca więźniów może obniżyć koszty przeznaczane na utrzymanie systemu więziennictwa i ponoszone przez podatników. Dodatkową wartością jest to, że zatrudnieni więźniowie pozwalają firmom z otwartego rynku pracy na wypełnienie luk kadrowych, a koszty ich zatrudnienia są niższe niż w przypadku zwykłego pracownika (na podstawie danych Centralnego Zarządu Służb Więziennych). Ten ostatni aspekt jest szczególnie zauważalny w przypadku prac fizycznych, jako że $70 \%$ osadzonych to osoby o niskim poziomie wykształcenia (http://www.rp.pl/Przestepczosc/170928957Prof-Wieslaw-Ambrozik-Miec-wiezniow-jak-w-Niemczech.html\#ap-1 [data dostępu: 30.09.2017]). Dodatkowo ci więźniowie, którzy pracują na rzecz samorządów lokalnych, pozwalają na zaoszczędzenie przynajmniej części pieniędzy publicznych, które trzeba by było przeznaczyć na zatrudnienie pracowników, np. służb porządkowych.

\section{Społeczny odbiór pracy więźniów}

Społeczeństwo polskie wydaje się nie mieć jasno sprecyzowanej opinii odnośnie pracy więźniów. Analizując chociażby publikację Anety Domżalskiej (2013, s. 132-136), łatwo można dojść do wniosku, że z jednej strony dość powszechny w potocznej opinii jest pogląd, że powinni oni pracować, i to wykonując ciężką pracę fizyczną lub taką, której nie chcą wykonywać inni, z drugiej strony wiele osób uważa, że pracujący więźniowie odbierają pracę osobom na wolności. Jest to znacząca niespójność, ponieważ skoro uważamy, że więźniowie powinni pracować, to należy też udostępnić im taką możliwość. Również pracodawcy mają opory przed zatrudnianiem więźniów. Różne są też zdania na temat tego, czy za swoją pracę więźniowie powinni otrzymywać wynagrodzenie. Wyniki badań przeprowadzonych w kwietniu 2017 roku przez portal trojmiasto.pl (ankieta zamieszczona pod adresem: https://praca.trojmiasto.pl/Program-Praca-dla-wieznia-Pracuje-juz45-proc-osadzonych-n111899.html [dostęp: 30.09.2017]) wskazują, że na pytanie: „Czy twoim zdaniem więźniowie powinni dostawać wynagrodzenie za swoją pracę?" aż 20\% respondentów odpowiedziało przecząco, uznając, że sama możliwość wyjścia do pracy i braku nudy powinna być dla nich wystarczającą motywa- 
cją i nagrodą. Zdecydowana większość pytanych, bo $68 \%$, odpowiedziała, że co prawda więźniowie powinni otrzymywać wynagrodzenie za wykonywaną przez siebie pracę, jednak pewna część tego wynagrodzenia powinna być im odbierana na pokrycie kosztów pobytu w więzieniu. $12 \%$ respondentów uznało, że więźniowie powinni otrzymywać takie samo wynagrodzenie, jak osoby pracujące na wolności.

\section{Podsumowanie}

Z perspektywy aktywizacji więźniów wprowadzenie programu „Praca dla więźniów" należy uznać za pożyteczne i bardzo potrzebne. Aktywizacja osób przebywających w zakładach karnych jest kwestią niezwykle istotną i pozwalającą na lepsze efekty resocjalizacji. Konieczne jest jednak dopracowanie już istniejących rozwiązań, dotyczących chociażby zdobywania kwalifikacji przez więźniów, ponieważ oferta kursów czy szkoleń, pomimo że jest dostępna, wydaje się w niewystarczającym stopniu zaspokajać potrzeby. Ten sam postulat dotyczy kwestii terapii dla więźniów, zdarzają się bowiem przypadki, w których czas oczekiwania na terapię w zakładzie karnym jest dłuższy niż sam wyrok (Mrózek, 2014, s. 51). Być może słuszne byłoby przemyślenie takich rozwiązań w zakresie kierowania na leczenie odwykowe, które będą uwzględniać przewidywany czas pobytu danego więźnia w zakładzie karnym. Pomimo że, jak się wydaje, wciąż pewne obszary objęte programem wymagają dopracowania, to jest on z pewnością pomysłem wartym kontynuowania, a nawet rozwoju. Jedną z kwestii, nad którymi wciąż należy się pochylać, jest problem niechęci społeczeństwa do kontaktu z więźniami, choć ich praca może przynosić wiele społecznych korzyści.

\section{Bibliografia}

Domżalska A., 2013: Sytuacja bytych skazanych na rynku pracy. „Forum Pedagogiczne" nr 2, s. $127-148$.

Goffman E., 2011 [1957]: Instytucje totalne. O pacjentach szpitali psychiatrycznych i mieszkańcach innych instytucji totalnych. Gdańsk: Gdańskie Towarzystwo Psychologiczne Profesjonalne.

Kubat K., 2010: Kwestia wykluczenia społecznego w kontekście funduszy unijnych. „Prace Etnograficzne", z. 38, s. 139-147.

Kubicki O., 2016: Praca dla więźniów. „Na wokandzie”, nr 29, s. 8-10.

Łuczak E., 2016: Współczesne problemy resocjalizacji penitencjarnej i ich minimalizowanie. „Lubelski Rocznik Pedagogiczny”, T. 35, s. 109.

Mrózek Ł., 2014: Zjawisko wykluczenia społecznego więźniów i osób opuszczających ośrodki penitencjarne. Analiza problemu i możliwości przeciwdziałania zjawisku. „Studia Social Cracoviensia”, T. 6, s. 54. 
Pstrąg D., 2014: Praca w procesie readaptacji społecznej skazanych. „Lubelski Rocznik Pedagogiczny", T. 33, s. 135-148.

Stanowska O., 2014: Zatrudnienie skazanych pozbawionych wolności na podstawie skierowania do pracy. „Rocznik Administracji i Prawa”, T. 14/1, s. 213-228.

\section{Akty prawne}

Kodeks karny wykonawczy, rozdz. 5, art. 124.

Międzynarodowy Pakt Praw Obywatelskich i Politycznych, art. 8, ustęp 3.

Ustawa z dnia 6 czerwca 1997 r. Dz.U. 2018, poz. 652.

Ustawa z dnia 28 sierpnia 1997r o zatrudnieniu osób pozbawionych wolności, Dz.U. 2017, poz. 2151.

Wyrok z dn. 23.02.2010 r. Sygn. akt P20/09.

\section{Źródła internetowe}

https://www.sw.gov.pl/strona/ministerialny-program-pracy-wiezniow [dostęp: 30.11.2018]. http://www.rp.pl/Przestepczosc/170928957-Prof-Wieslaw-Ambrozik-Miec-wiezniow-jakw-Niemczech.html\#ap-1 [dostęp: 30.09.2017].

https://praca.trojmiasto.pl/Program-Praca-dla-wieznia-Pracuje-juz-45-proc-osadzonychn111899.html [dostęp: 30.09.2017].

https://pl.globalvoices.org/2012/08/brazylia-jedna-przeczytana-ksiazka-to-o-cztery-dnikrotszy-pobyt-w-wiezieniu/ [dostęp: 30.09.2017].

http://www.tvp.info/28094640/wiezniowie-lataja-dziury-na-rynku-pracy-odplatnie-pra cuje-juz-125-tys-skazanych [dostęp: 6.09.2017].

http://docplayer.pl/5393378-Praca-skazanych-w-polskim-systemie-penitencjarnym-od1925-r.html [dostęp: 20.11.2017]. 